\title{
Challenges, Opportunities and Sustainability of Community Forest Associations and Water Resource Users Associations: A case of Kilungu catchment, Kenya
}

\author{
Patricia Mumbi Wambua*, Nzioka John Muthama and Thuita Thenya \\ Wangari Maathai Institute for Peace and Environmental Studies, University of Nairobi
}

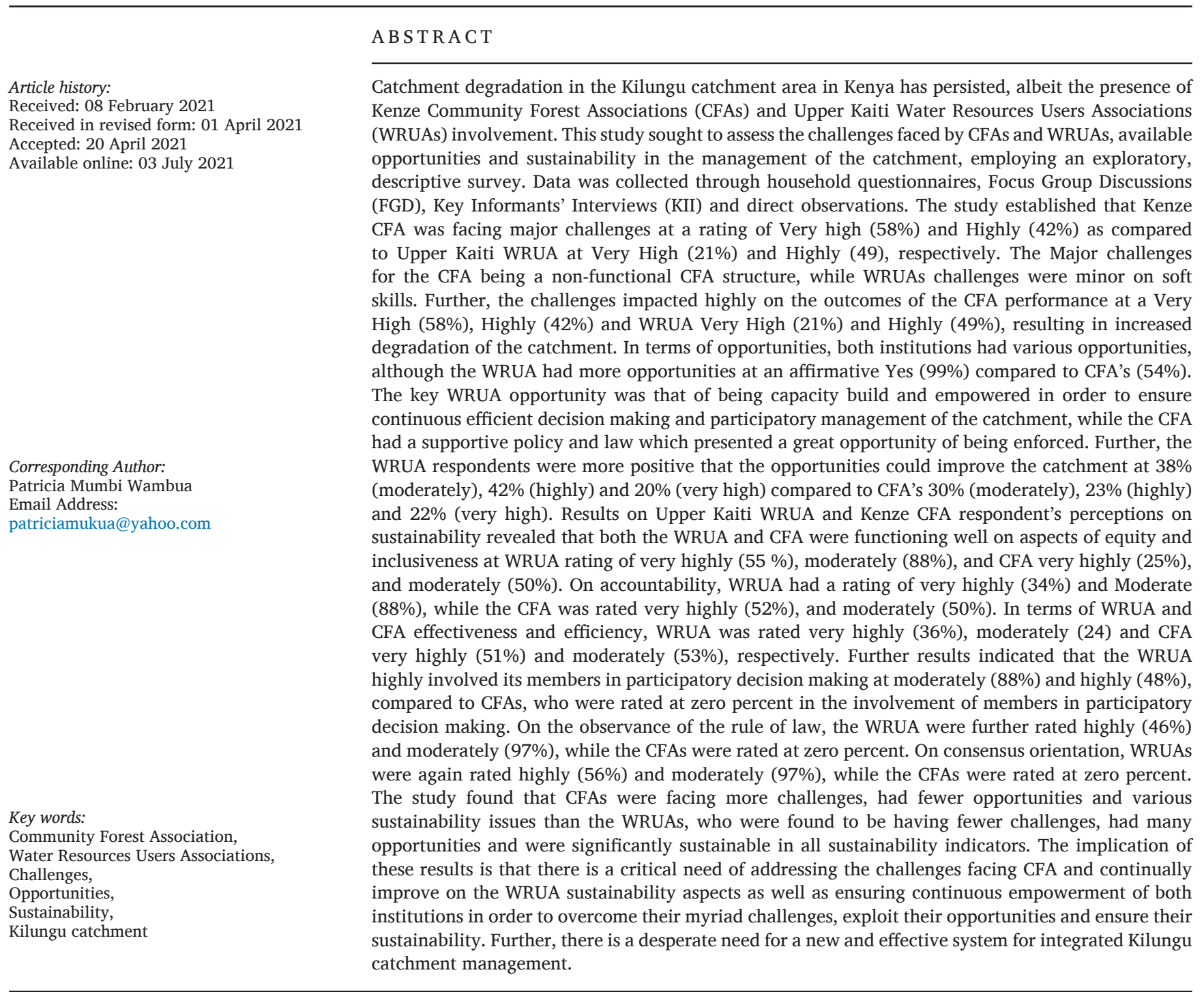

\section{Introduction}

Globally there has been an increased concern for the environment and catchments specifically, the degradation of the catchments, land, water and air through overexploitation, pollution and depletion of the natural resource (Glazewski, 1999). Further, the reason behind catchment 
degradation, even in the presence of Community Forest Associations, according to a study done in Mt. Kenya in Hombe and Gathiuru forest, is because the CFAs are faced with the challenge of inequality, among other (Thenya et al., 2017). Further, Community Forest Associations (CFA) are weak in performing their functions, and as such, the institutions need strengthening to enhance their adaptive capacity (Thenya et al., 2014).

They lack the capacity to run forests, and therefore they are forced to bring in technical people to help them in the technicalities of forest management (Ongugo et al., 2008) . On the other hand, Water Resource Users Associations also face various challenges. For instance, (Murtinho et al., 2013) reported that external financial support significantly enhanced the capacity of local communities to adapt to water scarcity in Columbia. Past studies reveal that in order to address the catchment challenges, there have been concerted efforts by several governments and stakeholders, especially in the drylands of Africa, where both statutory and traditional governance plays a major role in water management to engage quickly in order to reverse the trend (van Koppen et al., 2014).

Locally, Kenya has shifted to decentralised control over water resources amidst the challenge of growing scepticism around the application of Integrated Water Resources Management (IWRM). Kenya has done so by applying the IWRM framework and associated Dublin principles, paired with a participatory approach to water management (Molle, 2008; Allouche, 2016). Further, the Water Governance Centre cites WRUAs water governance capacity as a key challenge impacting negatively on their catchment management (WGC, 2015). According to (Ribot et al., 2006) communities that come together to form the Community Forest Associations are not homogenous and this affects their effectiveness CFAs and WRUAs have been identified as key instruments in improving forest cover and water access and availability, especially in the areas where land degradation and low rainfall have limited the capacity of ecosystems to provide adequate water resources (Murtinho et al., 2013). The study was carried out in Kilungu catchment area, which is in Makueni county. Makueni county falls within the Athi river basin catchment. It has nine (9) registered CFAs, namely: Makuli, Nzaui, Kamukima, Nthangu, Kitondo, Mbooni Community Forest Association (MBOCOFOA), Kichapa, Makongo and Kenze, respectively, and sixty-eight (68) registered WRUAs involved in various catchments management within the county. Due to erratic rainfalls, the communities along the Kaiti River collaborated to form a WRUA in order to manage the river resources and hence Upper Kaiti WRUA, formerly known as Kinzuma was formed in mid-2010. According to the (County Government of Makueni (CGM) County Integrated Development Plan (CIDP), 2018), Upper Kaiti WRUA and Kenze CFAs, both formed in 2013, are the only institution currently in place managing the entire Kilungu catchment. Additionally, the institutions are the only ones involved in the management of the catchment's various tributaries of Kaiti river, Kikoko, Kisusyo, Isuuni river, Mitungu, Tiva, Mwanyani, Katulye, Kyau, Kaiti, Kilumwa, Kwanthi (County Government of Makueni (CGM) County Integrated Development Plan (CIDP), 2018).

This study was informed by the fact that, even with the presence of these institutions, the catchment has experienced rampant degradation, which is undermining the limited sustainable water and forest resources base in the country and these calls for vibrant CFA and WRUA activities, having minimal challenges, optimising their opportunities and sustainable enough in order to reverse the trend (County Government of Makueni (CGM) County Integrated Development Plan (CIDP), 2018).

Further, Kilungu catchment is of major economic and ecological importance in the area due to its value as a watershed and catchments area for the above rivers as well as it being a source of various springs, namely Kikoko, Ilima, Kisusyo, which is the source of Kisusyo river and tributaries and wetlands providing water to the community and supporting various livelihood activities. Literature reveals that the catchments population of more than 23,956 people made up of 4,372 households is spread out within the seven forest blocks of Kilungu, Kitumbuuni, Ndaatai, Kiongwani, Kenze, Nduluni, and Kiio and its an epicenter of ecological support system for their livelihoods, agreeing with previous studies which found out that the catchment management leads to improvement of environmental quality and food security (Paudel, et al.,2014). Additionally, the challenges, opportunities, and sustainability of all the CFAs and WRUAs involved in the various catchment management activities and their contributions in the county are unknown according to Makueni County Integrated Development Plan, 2018-2022. Again, inadequate data on the challenges, opportunities and sustainability of the CFA and WRUA within the area makes it difficult for developers to make informed and transparent decisions on the sustainable utilisation of the catchment (County Government of Makueni (CGM) County Integrated Development Plan (CIDP), 2018).

The study was conducted in Kilungu sub-county in Makueni County, and this was informed by both the institutional and change theory. The institutional theory provided the theoretical lens through which the researcher established the challenges faced by Community Forest Associations (CFAs) and Water Resource Users Associations (WRUAs), available opportunities, and assessed the sustainability of the Community Forest Associations (CFAs) and Water Resource Users Associations (WRUAs) in management of the Kilungu catchment (Baumol et al., 2007; Brunton et al., 2010; Hirsch, 1975; Lai et al., 2006). The theory further aided in attending to the deeper and more resilient aspects of CFA and WRUA Challenges, opportunities and sustainability indicators. On the other hand, the Theory of Change (ToC) was also adopted since it was found to guide the study in 
making explicit the logic of how proposed CFA and WRUA intervention such as exploiting their opportunities, were expected to produce results by describing through the guided questionnaires what the study intended to achieve (Vogel, 2012). Additionally, one of the key objectives of these study was to assess the sustainability of the Community Forest Associations (CFAs) and Water Resource Users Associations (WRUAs) in the management of the Kilungu catchment, and this was well guided by the theory of change (ToC). This was supported by the fact that the key aspect of the ToC is in its contribution to structuring meaningful measurement of success indicators of institutions such as the CFA and the WRUA (Davies, 2018). The theory also provided an approach to flexible institutional adjustments during the life of desired intervention which ensure sustainability (Maru et al., 2018b; Thornton et al., 2017). This theory was applied to answer the following specific questions to this study: The challenges faced and available opportunities of the Community Forest Association (CFAs) and Water Resource Users Associations (WRUAs) in the management of the Kilungu catchment? Furthermore, how is the sustainability of the CFAs and WRUAs in managing the Kilungu catchment? This paper, therefore, discusses the challenges, available opportunities, and sustainability of the CFAs and WRUAs by exploring what challenges exist, how they can be addressed and opportunities seized, purposely to ensure the sustainability of the CFAs and WRUAs contributions to catchment management. The study is further supported by the guiding principle of agenda 21 adopted in 1992 at the Rio de Janeiro and in 2002 World Summits on Sustainable
Development in South Africa, which gave emphasises the importance of community management of catchments and services backed by measures to strengthen local institutions such as Water Resources Users Associations and Community Forest Associations in implementing basic service programmes (Doe and Khan, 2004).

\section{Methodology}

\subsection{Study area description}

The catchment covers an area of 615.1ha, with the plantations covering 253.8ha as shown in Fig. 1. It is divided into seven (7) forest blocks which further formed the study sample clusters, namely: Kilungu, Kitumbuuni, Ndaatai, Kiongwani, Kenze, Nduluni, and Kiio for ease of management and governed by Kenze Community Forest Association (CFA) and Upper Kaiti Water Resources Users Associations (WRUA). The rainfall received in the catchment is bimodal, with the long rains occurring between March and May and the short rains between October and December. Mean annual rainfall ranges from 800 to $1200 \mathrm{~mm}$. The area is endowed with well-drained soils which are extremely shallow and moderately deep to very deep, with an acid humic top layer. Two of the most important rivers traversing the Kilungu catchment include Kaiti and Kikuu rivers. The catchment is also the source of rivulets such as Mwanyani, Katulye, Kyau, Kaiti, Kilumwa, Kwanthi and Kilome Springs (County Government of Makueni (CGM) County Integrated Development Plan (CIDP), 2018). There are three major

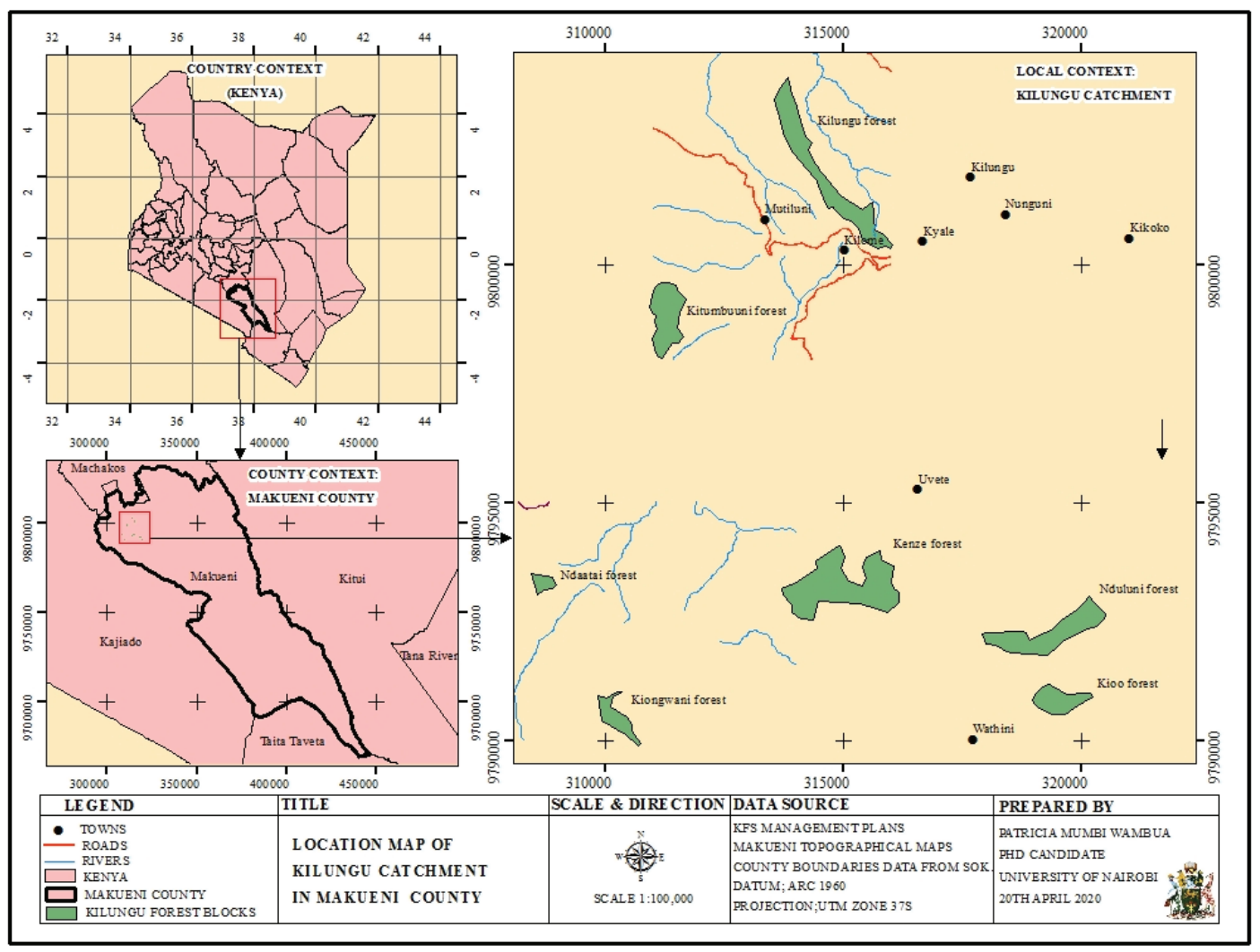

Fig. 1: Study area. Source: Ministry of Environment and Forestry, 2020 
springs in the catchment which are managed by the two institutions: Kilumwa, Kwanthi and Kilome water spring which are protected and serve as sources for water to the local communities to as far as $6 \mathrm{~km}$. The spring further serves the neighbouring schools, and the Kenya Forest Service uses the water for their tree nursery establishment (KWTA, 2019). Further, the catchment is surrounded by humans whose activities have led to high rates of catchment degradation, severely reducing water catchment capacity (Ontiri and Robinson, 2015).

\subsection{Sampling and sample size}

Cluster sampling was used to divide the entire catchment into seven clusters: - Kilungu, Kitumbuuni, Ndaatai, Kiongwani, Kenze, Nduluni, and Kiio. Each cluster represented a block of the catchment. A total sample size of the community stakeholders was obtained through Cochran's formula by Rucker (2017) as follows based on a total household population of 4372 .

$$
n_{o}=\frac{Z^{2} p q}{\left(e_{p}\right)^{2}}
$$

where $n_{o}=$ Cochran's sample size recommendation; = value (i.e. 1.96 for $95 \%$ confidence level); $p=$ proportion of the population with direct attribute to the sub-catchment governance; $e_{p}=$ desired level of precision-confidence interval $\pm 7 \%=( \pm 0.07)$ ) and population proportion $=$ $50 \%$.

Data was collected by equally sharing the 366 household questionnaires targeting the community members within the seven clusters of Kilungu, Kitumbuuni, Ndaatai, Kiongwani, Kenze, Nduluni and Kiio. Within each cluster data collection was done within a $5 \mathrm{~km}$ radius since this is the area with the greatest human-catchment interactions (Okumah et al., 2019). The information was collaborated by focus group discussions,10 Key Informants Interviews (KII) and direct observations. The collected data was on the CFAs and WRUAs challenges, available opportunities, and their sustainability in catchment management. Descriptive analysis was used through cross-tabulation in order to show the relationship between the two institutions of CFA and the WRUA. Information was presented in figures, tables and cross-tabulation.

\section{Results and Discussions}

\subsection{Characteristics profile of the respondents}

\subsubsection{Legal administration status and study population}

The Key Informants Interviews (KII) established that for ease of administration and management, and further to assist the study, the area was divided into seven (7) study clusters: Kilungu (676) Households (HH), Kitumbuuni (1282), Ndaatai (730), Kiongwani (370), Kenze (379), Nduluni (216) and Kiio (719) making a total of 4372 households, Fig. 2 below. Further, Kenze CFA and Upper Kaiti WRUA were the only associations engaged in the management of the catchment.

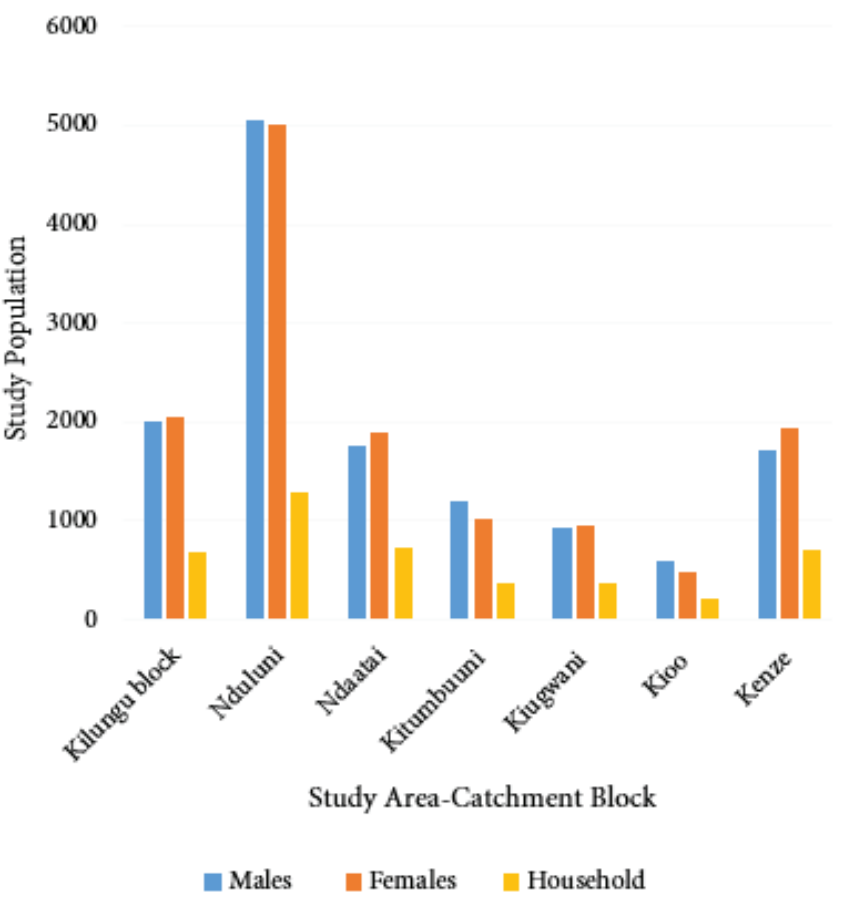

Fig. 2: Legal and administrative Status of the study area and the study population

\subsubsection{Respondents age in years}

The results showed that adults between the ages of 36-50 were the majority; Kenze CFA (45\%) and Upper Kaiti WRUA (33\%), followed by age range 51-65 at Upper Kaiti (32\%) and Kenze CFA (17\%), 21-35 at Upper Kaiti (17\%) and Kenze CFA (32\%), 66- 80 at Upper Kaiti (16\%) and Kenze CFA (11\%) and 81- 95 at Upper Kaiti (1\%) and Kenze CFA (0\%) as shown in Fig. 3.

Focus Group Discussions (FGD) established that adults between the ages of 36 and 65 dominated the study. This was said to be critical in understanding and explaining the challenges and the opportunities of the CFAs and WRUAs in catchment management due to the experience of the respondents gained over the years in reference to the catchment. Key Informant interview (KII) participants revealed that the age of the household head was among the demographic factors influencing the participation status of the household. There was no upper limit on age but the oldest respondent was 83 years. These results implied that the age structure of the respondents is concentrated at the age group of between 36-65 for both the CFA and WRUA revealing middle age of the respondents with a total cumulative percent of $77 \%$ for CFA and $48 \%$ for WRUA. 


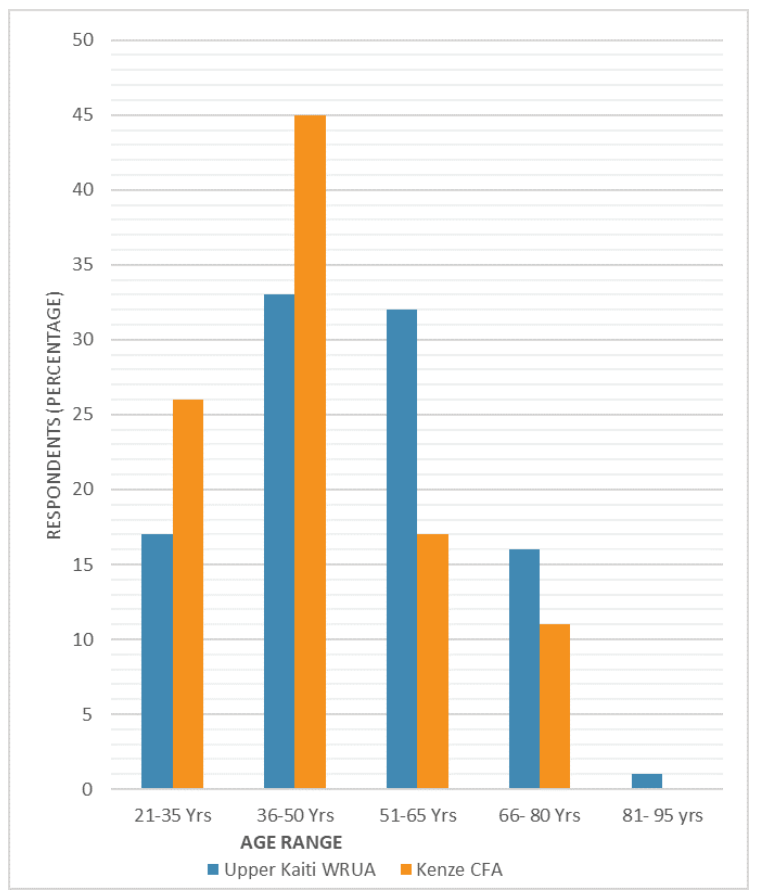

Fig. 3: Upper Kaiti WRUA and Kenze CFA Respondents age

\subsubsection{Gender and education of the respondents}

\subsubsection{Gender of the respondents}

More male participated more in CFA (58\%) as compared to females $(42 \%)$, in contrast with more females WRUA respondents $(62 \%)$ as opposed to males (38\%), Fig 4 . The FGD and KII confirmed the high participation of males in CFA was attributed to the fact that the study was touching on challenges in reference to catchment and men assume leadership on issues touching on catchment challenges. Secondly, men culturally, are deemed automatically the head of the family, especially on land use matters and women solely depend on their spouses and/or male relatives for their livelihood security and survival wellbeing despite obvious provisions by several Constitutions world over (Ifejika Speranza et al., 2016; Lastarria-Cornhiel et al. 2014; Bikketi et al. 2016). This further agreed with studies done earlier, which confirmed that, women share a common set of gender-based disadvantages in reference to natural resources management institutions (Bikketi et al. 2016; Farnworth and Shiferaw, 2012; Ifejika Speranza et al., 2016). Women tend to have less access than men to productive resources like water, land, livestock, and labour among others (Bikketi et al. 2016; Ifejika Speranza et al., 2016). The high number of women respondents in WRUA study was attributed to WRUA mandate on water related issues and the women being the most affected when water catchment related degradation occurs, agreeing with previous studies which revealed that involving women equally as men in catchment management activities and in institutions such as WRUA and even CFA increases their effectiveness and sustainability (World Bank et al., 2008; Forch et al., 2005). The FGD and the KII discussions added that the institutions should involve both genders equally for effective catchment management. This was in support of previous findings, which found that it's important to involve equally men and women in catchment management (Ifejika Speranza et al., 2016).

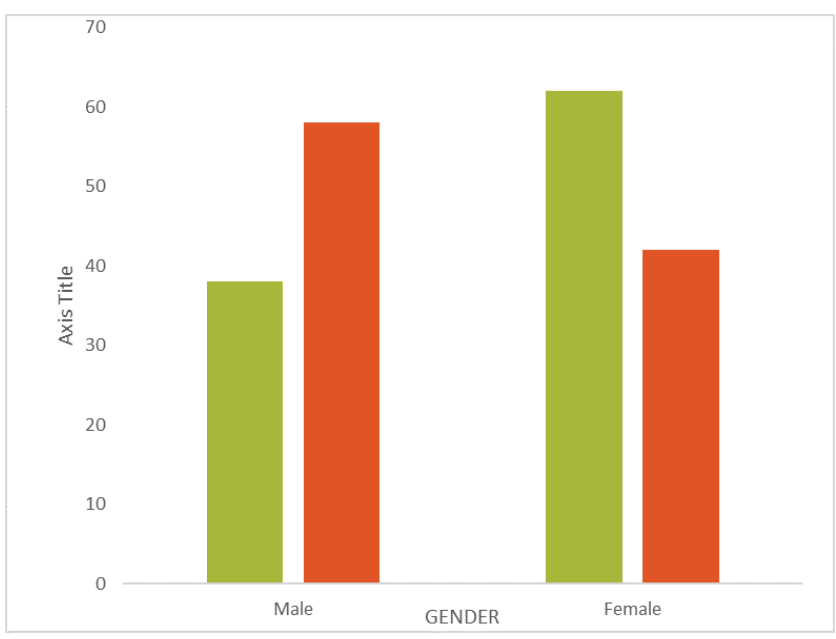

Fig. 4: Gender of the Upper Kaiti WRUA and Kenze CFA respondents

\subsubsection{Education level of the respondents}

In terms of level of education, the Kenze CFA respondents had the highest levels of education with Secondary level (36\%), College (28\%) and University (3\%) as compared to Upper Kaiti WRUAs (25\%) Secondary level, College certificate $(11 \%)$ and none with a University degree respectively, Fig. 5.

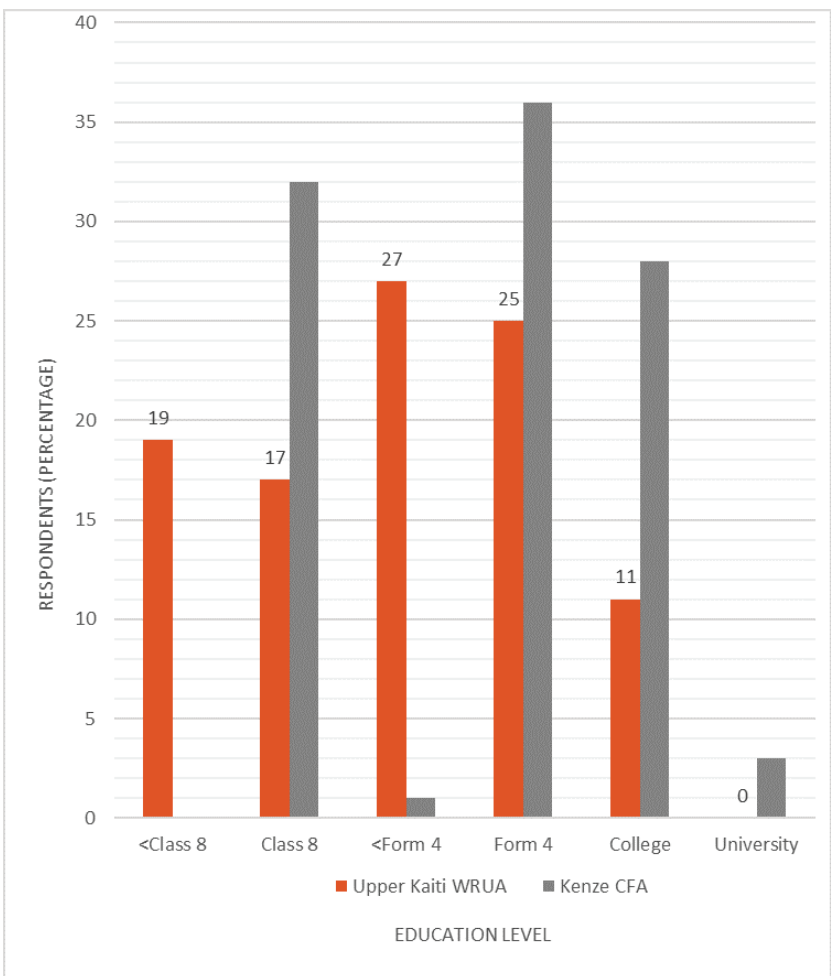

Fig. 5: Respondents' level of education 
Respondents who had attained college and other higher level of education comprised mostly of the county departmental heads and key respondents interviewed in this study.

These findings supported and agreed with Focus Group Discussions (FGD) outcomes which supported the idea that members of the community involved in community's work ought to have some level of education so as to effectively champion development actions within their area. The results from the FGD agreed with a study on community participation in social forestry in Zathila and Betaga villages in Gazipur, Bangladesh, by (Chowdhury 2004) who found out that people's level of education influenced their participation in forestry and catchment projects. Further, the results agree with the assertion that contemporary leaders and especially chiefs in Kenya need some level of education for effective resource management and community development. The findings of this study are also similar to that from Kenya Demographic Health Survey (KNBS and ICF Macro, 2010) in which majority of the rural population were found to have some primary education. Even though previous studies show education to be key factor in catchment management, the current study's observation was that education did not largely determine the CFA and WRUA participation in catchment management.

\subsection{Perceptions on Effects of upper Kaiti WRUA and Kenze CFA challenges on the management of the catchment.}

As shown in Fig. 6, the level of respondent's perceptions on challenges faced by Upper Kaiti WRUA and Kenze CFA which have effects on the catchment management were ranked from Low, Moderate, high to Very high. Likert scale rank was applied.

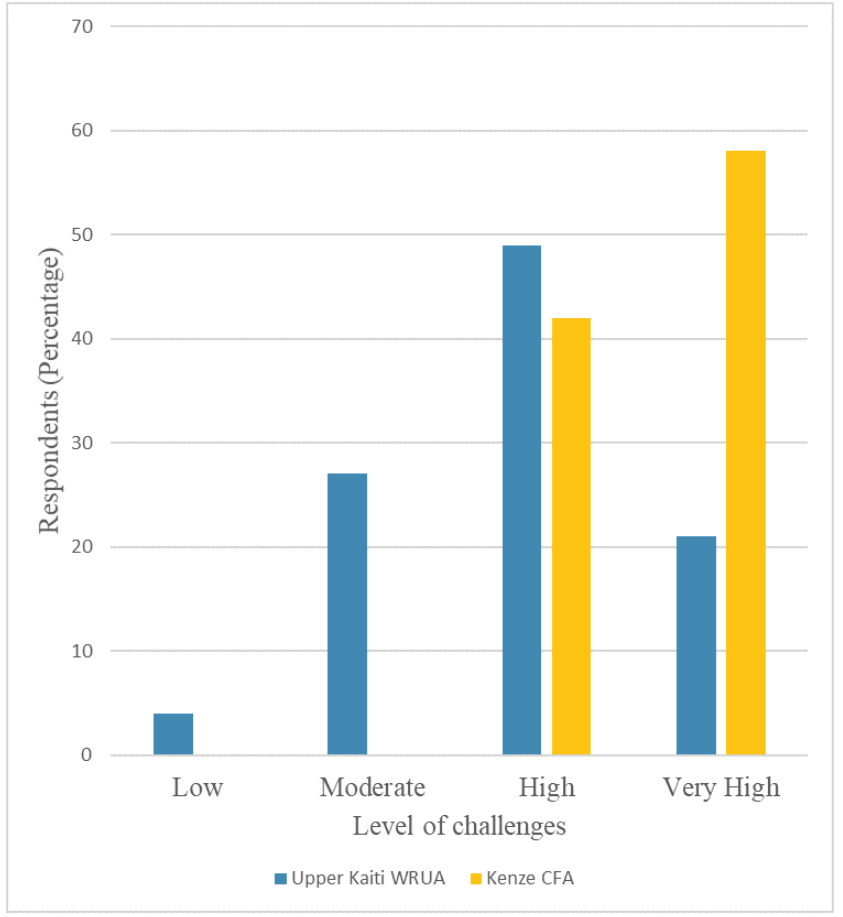

Fig. 6: CFA and WRUA level of challenges
On cross tabulation to compare between the CFA and WRUA respondents' perception on the matter, the results revealed that Kenze CFA was facing major challenges affecting their governance at very high (58\%) and high (42\%) as compared to Upper Kaiti WRUA at a very high rating of (21\%) and high (49). These was collaborated by the KII responses and FGD who mentioned CFA challenges as; a non-functional CFA structure, inadequate resources, lack of accountability, failure of some members to contribute funds, corruption allegations among the officials, lack of information, inadequate sharing of benefits, and a dictatorial tendency among some of the leaders.

Further, the KII revealed that leadership challenges emanated from lack of cohesiveness among the CFA members whereby officials were said not to consult members but only imposed decisions and this led to rebellion among the whole CFA institution.

These compared and agreed with previous studies done by (Ongugo et al., 2008) who found out that CFAs have many challenges, for example dictation of the official remained a major challenge in the operation of the CFAs and similar sentiments were echoed in a study done by (Matiku et al., 2013). Further results from KII were summarised by the Makueni County Ecosystem Conservator of Forests (MCECoF), Mr. Wakiaga who collaborating the FGD confirmed that CFA face various challenges as mentioned in the discussions. His sentiments further agreed with previous studies done and documented by (Thenya et al., 2014) who revealed that CFAs face many challenges which influence their outcomes in catchment management.

The MCECoF advised that the government should step in to address and mitigate against the myriad of CFA challenges which hinder their effective discharging of their statutory mandates. He further cited some of the key things the government should do. These includes initiation of community based income generating activities and enterprises, capacity building of the officials and members of the CFA through awareness creation, education for sustainable development, seminars, workshops and creation of catchment resources value addition centers.

On the other hand, KII responses and FGD indicated the WRUA challenges as; dealing with some self-centered persons with personal interests, inadequate facilitation, lack of WRUA capacity to handle community issues, scarcity of resources in terms of finances and logistics due to inadequate funding from the government and other stakeholders biasness in resolving conflicts due to diverse interest of the members, convincing the involved parties partly due to their low education levels, failure by management to meet specific targets and uncoordinated WRUA management structure. 


\subsection{Perceptions on the extent the challenges have led to catchment degradation}

When cross tabulation was done on the extent the challenges had led to catchment degradation, it was established that the challenges were found to be leading to high degradation of the catchment as they impacted highly on the outcomes of the CFA performance at a very high (58\%), highly (42\%) and WRUA very high (21\%) and highly (49\%) as shown in Fig. 7. This was supported by the KII which revealed that both the WRUA and CFA play a key role in reducing catchment degradation and water resources protection. The implication of these results is that there is an urgent need to address the CFA and WRUA challenges as a matter of priority in order to reverse the catchment degradation through making the CFA and WRUA sustainable. These findings are in agreement with previous studies by (Simon, 2012), who found out that WRUAs require varied and steady outside support to improve their performance until they reach sustainability stage. Further the results agreed with previous studies by (Thenya et al., 2007) who found out that communities had a slow up take of participation in management of forests and this enhanced the increased level of catchment degradation.

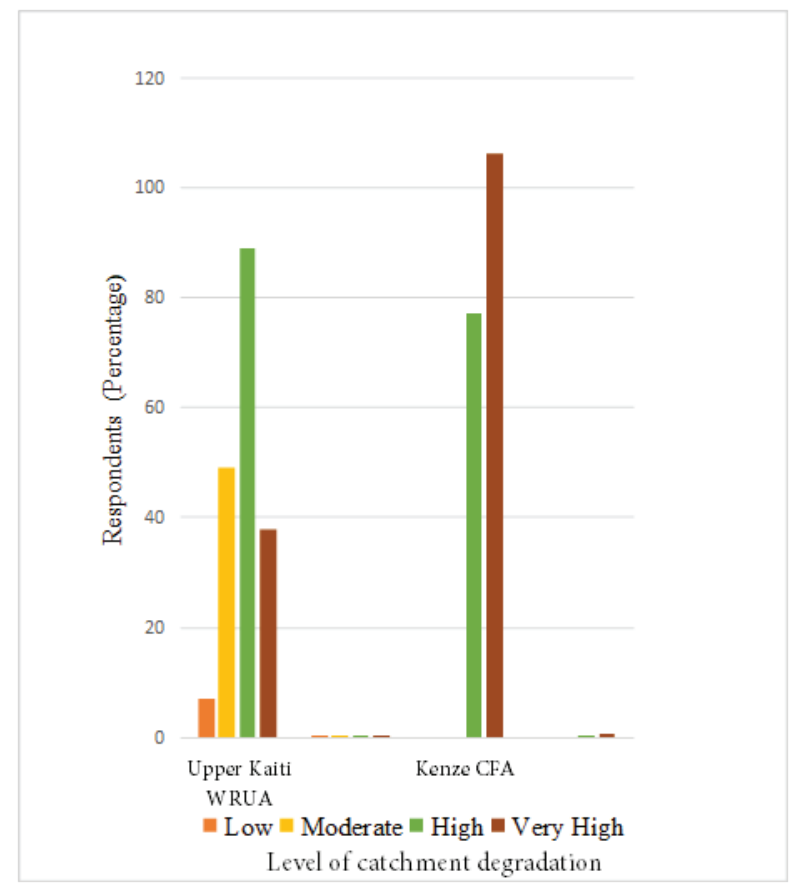

Fig. 7: Extend of catchment degradation due to challenges

3.4. Perceptions on opportunities available to the Upper Kaiti WRUA and Kenze CFA and them extend of improving the catchment

Results on the respondents' perceptions on opportunities available to the Upper Kaiti WRUA and Kenze CFA and the extend of improving the catchment revealed that both institutions had various opportunities. However, the WRUA participants cited major opportunities which if explored can improve the catchment at an affirmative yes of 99\%as compared to CFA's 54\%, as showed in Fig. 8. Further, the KII supported the position that there existed various opportunities for the WRUA and revealed that the WRUA present a great opportunity to being capacity build and empowered in order to be involved in efficient decision making and participatory management of the catchment.

Focus group discussions further supported that to promote improved performance of the WRUA in sustainability of catchment conservation and protection activities, communities of WRUA members should be given continued support by the government. Further they should be supported by donor agencies and local leadership. The support should be achieved through; institutional support mechanisms, formation of internal policies, legislation, proper monitoring and continued capacity building for members.

Further, the Water Resource Users Associations were found to provide an opportunity for the involvement of stakeholders and beneficiaries in the corporate management of water resources and resolution of water related conflicts. Again, they had an opportunity in promotion of water conservation practices as well as in promoting catchment conservation measures to improve water quantities and quality.

Comparably, the CFA opportunities were mentioned as: availability of supportive policy and law, cooperation and participation of community members, increasing number of community members joining Community Forest Association, dependence of community members on forest resources for their livelihood as well as introduction of income generating especially through collection of medicinal herbs. Other opportunities mentioned were: harvesting of honey, harvesting of timber or fuel wood, grass harvesting and grazing, collection of forest produce for community-based industries, ecotourism, recreational activities, scientific and educational activities, plantation establishments, carrying out specified forest operations and Continuous capacity building of CFA. This agreed with past studies done by (Kinyanjui et al., 2009) who asserted that CFA presents great opportunity of being capacity build and empowered in order to be involved in efficient decision making and participatory management the catchment. The KII cited the training of CFA members on conflict resolution, leadership and management skills, financial management, farm forestry and establishment of botanical gardens for medicinal plants as other key opportunities. 


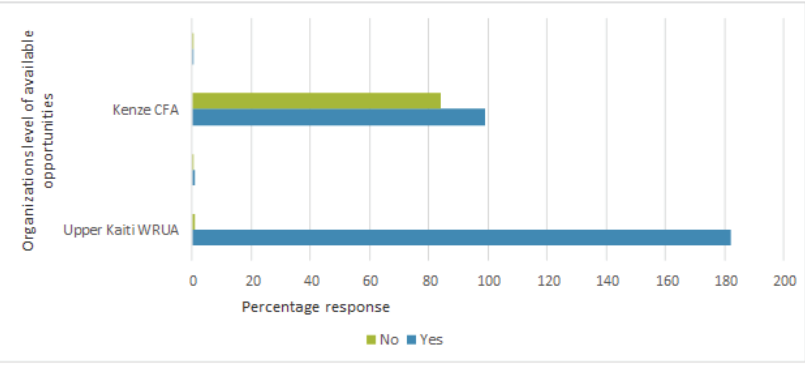

Fig. 8: Perceptions on opportunities available to the Upper Kaiti WRUA and Kenze CFA

\subsection{Perceptions on the like hood of the opportunities improving the catchment}

In regards to the perceived institutions available opportunities level of improving the catchment, WRUA respondents were more positive compared to the CFA respectively. Results showed that, out of all the WRUA respondents; 38\% respondent (Moderately), 42\% (Highly) and $20 \%$ (V. highly) as compared to CFA response of $30 \%$ (Moderately), 23\% (Highly) and 22\% (V. highly). This implied that more WRUA members were of the opinion that the opportunities improve the catchment and were more likely to implement same opportunities as showed in Fig. 9 as opposed to the CFA. This was supported by information gathered from the key informant groups who asserted that implementation of the available opportunities may improve the catchment, implying a strong need of the CFA and WRUA opportunities maximisation in order to enhance the catchment protection. These sentiments agreed with previous studies done by (Kinyanjui et al., 2009), who revealed that the CFA have opportunities including the opportunity of educating the community on the use and non-use aspects of the Kilungu catchment. Further, these results agreed with previous studies done by (Musyoki et al., 2013) and (Ongugo et al., 2008) who found out that there exist unexploited opportunities for CFA too.

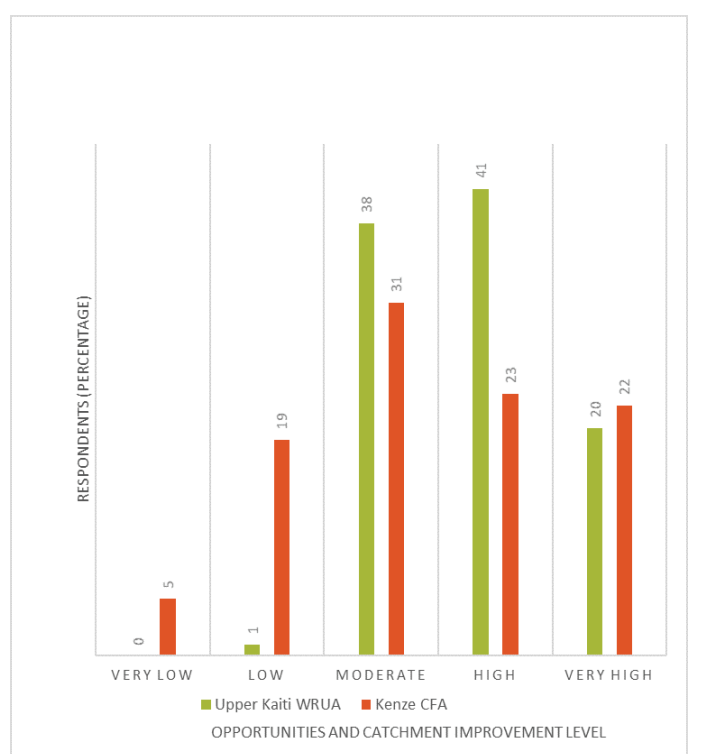

Fig. 9: Perceptions that opportunities improve the catchment
3.6. Perceptions on sustainability indicators of the Upper Kaiti WRUA and Kenze CFA in catchment management

Cross-tabulation between Upper Kaiti WRUA and Kenze CFA respondent's perceptions on their sustainability indicators revealed that both the CFA and WRUA were functioning well even though the WRUA were found better in various sustainability indicators as compared to the CFA. This was evidenced by performance on equity and inclusiveness at a rating of WRUA Very High (55\%), Moderate (88\%) and CFA Very High (25\%), Moderate (50\%), accountability at a rating of WRUA Very High (34 $\%)$ and Moderate (88\%) and CFA Very High (52\%), and Moderate (50\%) and in effectiveness and efficiency at a rating of WRUA Very High (36\%) Moderate 24 and CFA Very High (51\%), Moderate (53\%) respectively.

Further, results indicated that the WRUA had better rating on involvement of members in decision making, on observance of the rule of law and consensus orientation. In comparison, the CFA were rated at zero percentage in all the above aspects of involvement of members in decision making, on observance of the rule of law and consensus orientation portraying a dismal level of sustainability aspects as established in the results. WRUA was found to be more sustainable in involvement of its members in participatory decision making at Moderate (88\%) and High (48\%) compared to CFA who were rated at zero percentage on involvement of members in participatory decision making. On observance of the rule of law, the WRUA was rated at High (46\%) and Moderate (97\%) while the CFA was rated at zero percentage. On consensus orientation, WRUA was rated at High (56\%) and Moderate (97\%) while the CFA was rated at zero percentage as shown in Fig. 10.

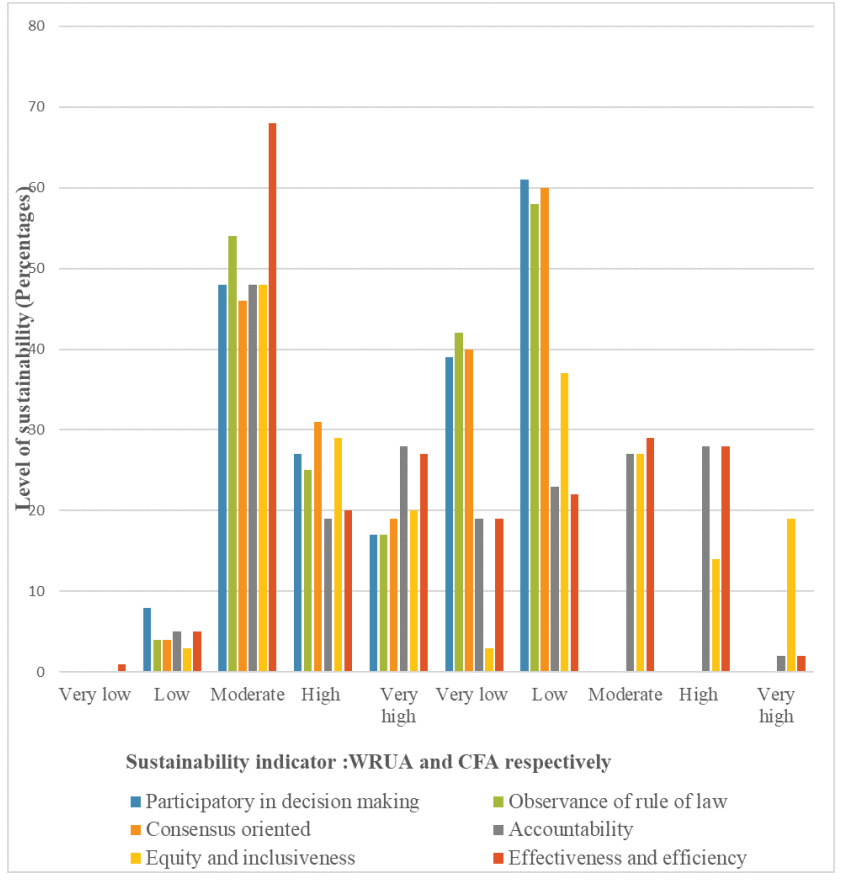

Fig. 10: Sustainability Indicators 
Discussions with the KII and FGD further revealed that for sustainable management of the catchment then the CFA and the WRUAs should get involved in all functions as required by law.

Respondents, confirmed that active participation of members in the catchment management activities was a sure way of ensuring the institutions sustainability especially if the members anticipated benefits from the activities and rewards from participation. These results agreed with previous studies by (Deji, 2007) on local women's associations' participation in rural community development projects in Nigeria who observed that provision of rewards to women's associations highly influenced their participation in development projects and ensured sustainability of the associations. Further discussions revealed some functions indicating their sustainability as: attending CFA meetings, nominating officials, active decision making, participating in scheduled catchment supervision, preventing illegal activities and preventing violation of catchment use rules.

Further, the KII and FGD indicated some other sure indicators of sustainable functioning of CFA and WRUA as: Participation in preparation of catchment management plans, being involved in catchment labor activities such as seedling nurseries, planting and thinning of trees, control of catchment fires, sensitizing communities on conservation and monitoring the catchment condition. Other indicators were: Monitoring activities carried out by other members and training members in nursery management and water use issues as well as capacity building the members on group dynamics.

The implications of these findings are that the Kenze CFA as it is to date, is not able to contribute effectively to the catchment management. This calls for enhanced Participation, observation of rule of law, consensus building, consensus orientation, effectiveness, accountability and efficiency aspects of CFA sustainability for them to ensure catchment management. The Upper Kaiti WRUA too should be continually monitored and reviewed in order to sustainably manage the catchment.

These results agree with Dublin statement (1992) that the ability of nations and societies to develop and prosper is linked directly to their ability to develop, utilise and protect their catchment resources. Further its collaborated by the earlier conferences conclusion that, "since water sustains all life, effective catchment management demands a holistic approach, linking social and economic development with protection of natural ecosystems" (Dublin Statement 1992). Further the sustainable use and holistic management of freshwater resources and catchments is the key to achieving the overall goal of sustainable development (Department of Environmental Affairs and Tourism 1998; Ministerial Declaration of the Hague on Water Security in the 21st Century 2000; UNESCO 2003).

\section{Conclusion and recommendations}

In conclusion CFA were facing more challenges which impacted on their performance, had fewer opportunities to exploit and had various sustainability aspects which needed attention compared to the WRUA who were found to be having fewer challenges, had many opportunities and were significantly sustainable in all the sustainability indicators. The implications of these findings are that there is an urgent need to address the CFA challenges, enhance the adoption of their opportunities and address all their sustainability challenges in order make them sustainable towards reversal of the catchment degradation

Policy makers should set standards and guidance for decision-makers to make better and more just decisions on sustainable CFA and WRUA institutions. The standards and guidance should be geared towards making the two institutions legitimate, transparent, accountable, inclusive, fair and functional to enhance their contributions to catchment management. A key approach to attain this priority is through CFA and WRUA support in all aspects of effective sustainable governance structures to ensure their sustainability and effectual sustainable management of the catchment.

The study recommends a new policy frame work for the implementation and monitoring of CFA and WRUA sustainability indicators. The study further recommends, continuous empowering of the CFA and WRUA in order to overcome their myriad challenges, exploit their opportunities and ensure their sustainability.

\section{Acknowledgement}

The authors are grateful to institutions and individuals who provided data and information towards this research. These include the Makueni county WRA office led by Stephen Ngao, WRUA chairman Antony Kimeu, Kaiti WRUA committee members, Makueni KFS office led by Mwanza and Veronica, foresters Kilungu catchment, CFA committee members, research assistants Daniel Ngoka and Muteti and Festus Mutiso for assistance in data collection and analysis. We also thank our colleagues from WMI who provided insight and expertise that assisted the research.

\section{Compliance with ethical standards}

The research was carried out under Wangari Maathai Institute for Peace and Environmental Studies of the University of Nairobi. Consent of participants in interviews and questionnaire survey was sought before each individual participant. Permission was sought and granted by National Commission for Science, Technology and Innovation (NACOSTI). 


\section{References}

Allouche, J. (2016). The birth and spread of IWRM - A case study of global policy diffusion and translation. Water Altern. 9(3), 412-433. Google scholar

Baumol, W. J., Litan, R. E., \& Schramm, C. J. (2007). Good capitalism, bad capitalism, and the economics of growth and prosperity. SSRN Electronic Journal. https://dx.doi.org/10.2139/ssrn.985843

Bikketi, E., Ifejika Speranza, C., Bieri, S., Haller, T., \& Wiesmann, U. (2016). Gendered division of labour and feminisation of responsibilities in Kenya; implications for development interventions. Gender, Place \& Culture, 23(10), 1432-1449. https://doi.org/10.1080/0966369X.2016.1204996

Bruton, G. D., Ahlstrom, D., \& Li, H.-L. (2010). Institutional Theory and Entrepreneurship: Where Are We Now and Where Do We Need to Move in the Future? Entrepreneurship Theory and Practice, 34(3), 421-440. https:// doi.org/10.1111/j.1540-6520.2010.00390.x

Chowdhury. S. Ahmed (2004). Participation in forestry: a study of people's participation on the social forestry policy in bangladesh: myth or reality. Google scholar

County Government of Makueni (CGM) (2018). County Integrated Development Plan 2018-2022 (CIDP). Government Printers in ecosystem management.

Campion, B., \& Acheampong, E. (2014). The Chieftaincy Institution in Ghana: Causers and Arbitrators of Conflicts in Industrial Jatropha Investments. Sustainability, 6(9), 6332-6350. https://doi.org/10.3390/su6096332

Davis. R (2018). Representing Theories of Change: Technical Challenges with Evaluation Consequences. https://doi.org/10.13140/RG.2.2.21085.46569.

Deji O. F. (2007). Community Socio-Cultural Factors Associated with the Participation of Local Women's Associations in Rural Community Development Projects in Nigeria. J. Social Sci., 2: 1-6. INSInet. Google scholar

Doe, S. R. \& Khan, M. S. (2004). The boundaries and limits of community management: Lessons from the water sector in Ghana. Community Development Journal, 39(4), 360-371. https://doi.org/10.1093/cdj/bsh032

Farnworth, C. R., \& Shiferaw, N. (2012). Forward looking assessment of HARVEST gender-responsive livelihood diversifications for vulnerable people. Prepared for the Swedish International Development Cooperation Agency (SIDA) Ethiopia team. Google scholar

Förch, G., Winnegge, R. and Thiemann, S. (Eds). (2005). DAAD Alumni Summer School 2005: Topics of Integrated Water Resources Management. Weiterbilding in Siegen 18. Google scholar

Förch, G. \& Deutscher Akademischer Austauschdienst. (2005). Topics of integrated watershed management DAAD alumni summer school 2005; proceedings. Google scholar

Glazewski J. (1999). Environmental law in South Africa. Durban: Butterwortt. Google scholar

Hirsch, P. (1975). Organizational Effectiveness and the Institutional Environment. Administrative Science Quarterly, 20(3), 327-344. https://doi. $\operatorname{org} / 10.2307 / 2391994$

Ifejika Speranza, C., Kiteme, B., Wiesmann, U., \& Jörin, J. (2016). Communitybased water development projects, their effectiveness, and options for improvement: Lessons from Laikipia, Kenya. African Geographical Review, 1-21. https://doi.org/10.1080/19376812.2016.1253485

Kenya National Bureau of Statistics (KNBS) \& ICF Macro (2010). Kenya Demographic and Health Survey 2008-09. Calverton, Maryland: KNBS and ICF Macro.

Kinyanjui, J.M. (2009) The Effect of Human Encroachment on Forest Cover, Structure and Composition in the Western Blocks of the Mau Forest Complex. $\mathrm{PhD}$ Thesis, Egerton University, Njoro.

Koech, C. K., Ongugo, P. O., Mbuvi, M. T. E \& Maua J. O. (2009). Community Forest Associations in Kenya: challenges and opportunities. Kenya Forestry Research Institute

KWTA (2019). Community Resource Assessment for Nzaui Water Tower.

Lai, K., Wong, C. W. Y., \& Cheng, T. C. E. (2006). Institutional isomorphism and the adoption of information technology for supply chain management. Computers in Industry, 57(1), 93-98. https://doi.org/10.1016/j. compind.2005.05.002

Lastarria-Cornhiel, S., Behrman, J. A., Meinzen-Dick, R., \& Quisumbing, A.
R. (2014). Gender Equity and Land: Toward Secure and Effective Access for Rural Women. In A. R. Quisumbing, R. Meinzen-Dick, T. L. Raney, A. Croppenstedt, J. A. Behrman, \& A. Peterman (Eds.), Gender in Agriculture (pp. 117-144). Springer Netherlands. https://doi.org/10.1007/978-94-0178616-4_6

Mehta, L., Derman, B., \& Manzungu, E. (Eds.). (2017). Flows and Practices: The Politics of Integrated Water Resources Management in Eastern and Southern Africa. Weaver Press. https://doi.org/10.2307/j.ctvh8r2qk

Matiku, P., Ogol, C., \& Mireri, C. (2012). The impact of participatory forest management (PFM) on forest integrity and biodiversity in Arabuko-Sokoke forest, Kenya. African Journal of Ecology, 50(2), 184-192. https://doi. org/10.1111/j.1365-2028.2011.01311.x

Maru Y, Sparrow A, Stirzaker R, Davies J. (2018a). Integrated agricultural research for development (IAR4D) from a theory of change perspective. Agric Sys 165:310-320. DOI https://doi.org/10.1016/j.agsy.2016.09.012.

Maru YT, Sparrow A, Butler JRA, Banerjee O, Ison R, Hall A, Carberry P. (2018b) Towards appropriate mainstreaming of "Theory of Change" approaches into agricultural research for development: Challenges and opportunities. Agric Sys 165:344-353. https://doi.org/10.1016/j.agsy.2018.04.010.

Molle, F. (2008). Nirvana concepts, narratives and policy models: insight from the water sector. Water Altern. 1(1), 131-156. Google scholar

Murtinho, F., Tague, C., de Bievre, B., Eakin, H., \& Lopez-Carr, D. (2013). Water Scarcity in the Andes: A Comparison of Local Perceptions and Observed Climate, Land Use and Socioeconomic Changes. Human Ecology, 41(5), 667-681. https://doi.org/10.1007/s10745-013-9590-z

Musyoki, J. K., Mugwe, J., Mutundu, K., \& Muchiri, M. (2013). Determinants of Household Decision to Join Community Forest Associations: A Case Study of Kenya. ISRN Forestry, 2013, 1-10. https://doi.org/10.1155/2013/902325

Okumah, M., Chapman, P., Martin-Ortega, J., \& Novo, P. (2018). Mitigating Agricultural Diffuse Pollution: Uncovering the Evidence Base of the Awareness-Behaviour-Water Quality Pathway. Water, 11(1), 29. https://doi. org/10.3390/w11010029

Ongugo, P.O, Obonyo E., Mogoi J.N., and Oeba V.O. (2008). The Effect of Internal Human Conflicts on Forest Conservation and Sustainable Development in Kenya. The Twelfth Biennial Conference of the International Association for the Study of Commons. Google scholar

Ontiri, E. \& Robinson, L.W. (2015). North lowland Ewaso Ngiro rangelands: Initial system analysis. International Livestock Research Institute report to the LGACC project. Google scholar

Paudel, B., Acharya, B. S., Ghimire, R., Dahal, K. R., \& Bista, P. (2014). Adapting Agriculture to Climate Change and Variability in Chitwan: LongTerm Trends and Farmers' Perceptions. Agricultural Research, 3(2), 165-174. https://doi.org/10.1007/s40003-014-0103-0

Ribot J. C., Agrawal A, Larson A. M. (2006). The decentralisation of natural resource management: theory meets political reality. World Dev 34:18641886. Google scholar

Rucker M. (2017). How to determine the sample size for your study category. Research Accessed on 20-2-19.

Simon, F. K. (2012). Influence of Community Capacity Building on Performance of Water Resources Users Associations in Water Catchment Management in Tharaka Nithi County. University of Nairobi. Google scholar

Thenya, T., Wandago, B. and Nahama, E. T. (2007). Participatory forest management experience in Kenya (1996-2006), In: Proceedings of the 1st National Participatory Forest Management Conference, KEFRI Headquarters, Nairobi, Kenya. Google scholar

Thenya T. 2014. Forest Based Income Generating Potential (IGP) high community expectations amidst low community transformation; an analysis of PFM implementation between 2005 and 2013. Proceedings of the Second National PFM Conference: Enhancing participatory forest management under the devolved governance structure. Kenya Forestry Research Institute, Muguga, Kenya. PP.104-110. Google scholar

Thenya, T. (2017). High community expectation against low societal transformation through community based income generating activities. Analysis of Participatory forest management in Kenya 2005-2013. International Journal of Scientific Research and Management. https://doi. org/10.18535/ijsrm/v5i6.02

Thornton, P., Schuetz, T., Förch, W., Cramer, L., Abreu, D., Vermeulen, S., \& Campbell, B. (2017). Responding to global change: A theory of change approach to making agricultural research for development outcome- 
based. Agricultural Systems, 152, 145-153. https://doi.org/10.1016/j. agsy.2017.01.005

van Koppen, B., \& Schreiner, B. (2014). Moving beyond integrated water resource management: Developmental water management in South Africa. International Journal of Water Resources Development, 30(3), 543-558. https://doi.org/10.1080/07900627.2014.912111

Vogel, I. (2012). "Review of the Use of 'theory of change' in International Development”, Review Report, Department for International Development. Review Report.
UNCED (1992) Agenda 21. Dublin statement (1992). Ministerial Declaration of the Hague on Water Security in the 21st Century. Google scholar

Water Governance Centre (WGC, 2015). Testing the capacity Assessment of tool on water governance on two WRUAs within the Lake Naivasha basin; Nairobi, Kenya

World Bank, AfDB, FAO, IFAD \& IWMI. (2008). Investment in Agricultural Water for Poverty Reduction and Economic Growth in Sub-Saharan Africa - A Synthesis Report. World Bank, Washington D.C., USA 